\title{
Relevant videnskabsteori - fagets videnskabsteori i kuhniansk perspektiv
}

\author{
Esben Nedenskov Petersen, ph.d., Forskningsprogrammet Viden og Værdier, \\ Institut for Kulturvidenskaber, Syddansk Universitet
}

\section{Reviewet artikel}

\begin{abstract}
Mens der er krav om, at fagets eller fagområdets videnskabsteori skal indgå i bacheloruddannelserne på de danske universiteter, er det lagt ud til de ansvarlige for de enkelte uddannelser at fastlægge fagets konkrete indhold. På grundlag af Thomas Kuhns beskrivelse af naturvidenskaben kan man dog fremføre gode grunde til, at undervisning i almene videnskabsteoretiske begreber og spørgsmål bør være en del af faget på de naturvidenskabelige uddannelser, da de studerende ellers vil mangle det teoretiske grundlag for at reflektere kritisk over deres egne fags metoder og forstå andre fags videnskabelige tilgange. Samtidig er undervisning i almen videnskabsteori på disse uddannelser imidlertid forbundet med den udfordring, at de studerende vil have en tendens til ikke at betragte den som relevant for deres videnskabelige profession. Hvis de studerende skal opnå det videnskabsteoretiske grundlag for tværfaglig forståelse og kritisk faglig refleksion, er det derfor afgørende, at undervisningen i almen videnskabsteori sigter efter at forbinde de abstrakte, overordnede diskussioner fra videnskabsteorien med spørgsmål fra konkret videnskabelig praksis.
\end{abstract}

\section{Introduktion: Fagets videnskabsteori og dets indhold}

Siden 2004 har det været indskrevet i bekendtgørelsen for bachelor- og kandidatuddannelserne ved de danske universiteter, at bacheloruddannelsernes konstituerende elementer skal omfatte fagets eller fagområdets videnskabsteori (Uddannelsesbekendtgørelsen, 2004:\$16 stk. 3). Den overordnede hensigt har fra begyndelsen været, at uddannelserne skal inkludere et delelement, der beskæftiger sig med fagenes "teoretiske, historiske, filosofiske baggrund set i forhold til andre og til det almene" (Vestager, 2001). Beslutningerne om, hvordan indholdet af fagets videnskabsteori (herefter FVT) nærmere skal specificeres og inkorporeres på de enkelte fag, er imidlertid lagt ud til de ansvarlige for uddannelserne på de forskellige fagområder på hvert enkelt af universiteterne. Endvidere kan man opliste en bred vifte af mulige områder, der kunne fokuseres på med henblik på at realisere den overordnede hensigt med fagelementet. Som Christensen (2005) beskriver, kunne FVT dermed tænkes at rumme en række forskellige perspektiver på fagene. Konkret nævner han historiske tilgange, idéhistoriske, sociologiske, samfundsmæssige, didaktiske, filosofiske, 
videnskabsteoretiske og etiske tilgange, som mulige perspektiver, der kunne indgå i FVT. Mulighederne for at forme FVT på de enkelte fag og fagområder er altså betydelige. At man med god ret kan problematisere de sondringer, som Christensen anlægger - eksempelvis adskillelsen af filosofiske og videnskabsteoretiske perspektiver - ændrer ikke grundlæggende på dette billede. Som jeg vil argumentere for, er det imidlertid uhensigtsmæssigt, hvis denne frihed generelt fører til, at undervisningen i overordnede videnskabsteoretiske begreber og problemstillinger minimeres eller helt forsvinder fra BA-uddannelserne på universiteterne. Mere specifikt vil artiklen fokusere på de naturvidenskabelige uddannelser og argumentere for, at der med hensyn til dem er vægtige grunde til at give almene videnskabsteoretiske diskussioner en betydelig plads i FVT. ${ }^{1}$

Grundlaget for denne konklusion henter jeg primært fra den indflydelsesrige karakteristik af naturvidenskaben, som man finder i Kuhns videnskabsteoretiske hovedværk The Structure of Scientific Revolutions (herefter SSR). På grundlag af Kuhns arbejde argumenterer jeg således for, at det først og fremmest er gennem undervisning i overordnede videnskabsteoretiske emner, at de studerende på de naturvidenskabelige fag kan opnå de teoretiske ressourcer til at reflektere over deres egne fags metoder og det nødvendige grundlag for at forstå andre fags videnskabelige tilgange. Samtidig argumenterer jeg imidlertid for, at der kan være betydelige didaktiske udfordringer i forhold til at formidle overordnede videnskabsteoretiske spørgsmål til de studerende på de naturvidenskabelige fag. Nærmere bestemt hævder jeg, at den praksisbundne forståelse af videnskabelige normer inden for naturvidenskaben kan medføre en tendens til, at overordnede diskussioner angående videnskabelige formål, idealer og normer vil blive opfattet som irrelevante af de studerende. Endelig diskuterer jeg på den baggrund hvilken tilgang til undervisningen i videnskabsteori, der vil være hensigtsmæssig på de naturvidenskabelige fag i forhold til at sikre de studerende et tilstrækkeligt videnskabsteoretisk grundlag for tværfaglig forståelse og kritisk faglig refleksion.

\section{Naturvidenskaben ifølge Kuhn og Collins}

Kuhns hovedsigte med SSR er et opgør med den opfattelse af naturvidenskabens historiske udvikling, der tidligere var dominerende blandt videnskabsteoretikere. Før SSR betragtede mange således naturvidenskabens udvikling som en jævn progression, hvor der hele tiden var blevet bygget oven på tidligere erkendelser, så naturvidenskabens samlede erkendelse efterhånden var blevet mere og mere omfattende (Bird, 2011:\$2). Imod denne kumulative opfattelse af videnskabens fremskridt pegede Kuhn på, at opfattelsen strider med de faktiske historiske forhold (Kuhn, 1970:1). Kigger man på videnskabshistorien, er der ganske vist lange perioder, der stemmer

\footnotetext{
${ }^{1}$ Jeg vil dog understrege, at der efter min opfattelse er mindst ligeså gode grunde til at undervise $\mathrm{i}$ almen videnskabsteori i FVT på uddannelserne inden for de øvrige videnskabelige hovedområder. Af pladshensyn kan disse imidlertid ikke diskuteres inden for indeværende artikels rammer.
} 
med forestillingen om en jævn progression. Men sådanne normalvidenskabelige perioder afbrydes af kortere revolutionære faser, hvor man bryder med den eksisterende tilgang og erstatter den med en ny, fremfor blot at bygge videre på tidligere erkendelser.

Denne type skift, hvor man gennem en videnskabelig revolution bevæger sig fra en normalvidenskabelig periode til den efterfølgende, redegør Kuhn for ud fra sit paradigmebegreb. Groft formuleret kan man forstå et paradigme som den forståelsesramme, som en given videnskabelig praksis udspiller sig indenfor. Når der inden for et underområde af naturvidenskaben indtræder en videnskabelig revolution, består den således $i$, at et paradigme opgives og erstattes med et nyt, som derpå bliver den forståelsesramme, man på det pågældende område arbejder inden for i den efterfølgende, normalvidenskabelige periode. Videnskabelige revolutioner kan på den baggrund beskrives som paradigmeskift. Kuhn ser altså videnskabshistorien som opdelt i lange perioder, hvor forskerne arbejder ud fra et fastlagt paradigme, og korte overgangsperioder, hvor man udskifter et paradigme med et andet.

Som eksempler på paradigmer nævner han bl.a. Aristoteles' Fysikken, Newtons Principia og Lavoisiers Traité élémentaire de chimie, der på hvert deres respektive område og udgivelsestidspunkt hævdes at have gengivet det alment accepterede korpus af teorier, illustrationer på deres succesfulde anvendelser og de vigtigste eksempler på de observationer og eksperimenter, som underbyggede teorierne (Kuhn, 1970:10). Ifølge Kuhn afgrænser de et undersøgelsesområde og definerer de typer af metoder, der betragtes som acceptable måder at besvare undersøgelsesområdets spørgsmål på.

Når et paradigme på den måde fungerer som grundlaget for arbejdet inden for et videnskabeligt område, er det imidlertid ikke ved at give forskerne et eksplicit formuleret sæt af regler, som de skal følge i deres praksis. Tværtimod er de normer og værdier, der ledsager et paradigme, generelt implicitte i den videnskabelige tradition, hvor paradigmet gør sig gældende (Kuhn, 1962:45-46). Fremfor at findes på lister i lærebøger, videregives de i stedet i og med, at naturvidenskabsfolk lærer deres profession (eng. 'trade') (Kuhn, 1970:46) ved at få udpeget en specifik type naturfænomener, som de lærer at bruge paradigmets centrale teorier og metoder på. Anvendelsen af teorier og metoder fremstår dermed som omdrejningspunktet for naturvidenskabelige uddannelser. Når man inden for de naturvidenskabelige fag lærer meningen med centrale teoretiske begreber at kende, sker det således ifølge Kuhn først og fremmest ved, at man observerer, hvordan begreberne anvendes i forbindelse med løsningen af videnskabelige problemer, og ved at man er med til at bruge dem i besvarelsen af videnskabelige spørgsmål. Denne indlæring beskrives endvidere som en "learning by finger exercise or by doing" (Kuhn, 1970:47), der fortsætter gennem hele den periode, hvor en person indvies i den videnskabelige profession. 
Den faglige kompetence, som naturvidenskabelige forskere besidder, består således ikke blot i kendskabet til en mængde specifikke videnskabelige teorier. Den bygger i mindst ligeså høj grad på en praksisbundet viden om, hvordan deres fag udøves. For så vidt, som de kender normerne for deres videnskabelige arbejde, er det altså først og fremmest fordi, de har lært de accepterede måder, som man gør tingene på, inden for deres fagområde. Forståelsen af normerne er dermed bundet til praksis i den forstand, at kendskabet til normerne er inkorporeret i måden man arbejder på, måden man gør tingene på i praksis.

Betydningen af praksis i de naturvidenskabelige fag påpeges også af sociologen $\mathrm{H}$. M. Collins, der argumenterer for, at udviklingen af ekspertise inden for naturvidenskabens fagområder følger, hvad han kalder indkultiveringsmodellen (eng. 'enculturational model') (Collins, 1992:57). Ifølge denne opfattelse læres de naturvidenskabelige fag gennem indkultivering, hvilket vil sige, at indlæringen kan sammenlignes med at tilegne sig sociale færdigheder, der gør det muligt at fungere inden for de normer, der gælder for bestemte sociale situationer. Med andre ord hævder Collins, at det, man lærer inden for de naturvidenskabelige fag, er, hvordan man gør tingene på den rigtige, accepterede måde, der så er identisk med den måde, man forlanges at agere på for at indgå i det fagligt-sociale fællesskab blandt medlemmerne af ens profession.

Både hos Kuhn og Collins finder man dermed grundlag for den antagelse, at studerende og forskere inden for de naturvidenskabelige fag primært vil få en praksisbundet forståelse af deres fags videnskabsteoretiske grundlag og normer så længe, undervisningen på deres studier udelukkende består af formidling af fagenes etablerede teorier og metoder. Anvender man Ryles klassiske skelnen mellem 'propositionel viden' og 'knowledge how', eller 'viden-hvordan' (Ryle, 1949; Bengson \& Moffett, 2012), kan man formulere det på den måde, at den faglige viden om normerne for videnskabeligt arbejde overvejende vil have form af en 'viden-hvordan', der primært viser sig som evnen til at deltage i det faglige arbejde, der inkorporerer normerne.

At kendskabet til de naturvidenskabelige fags værdier og normer for videnskabelighed er praksisbundet, betyder samtidig, at fagenes udøvere typisk ikke uden videre kan gengive deres viden om normerne. Selv færdiguddannede forskere kan iflg. Kuhn have vanskeligt ved at formulere de fundamentale regler eller principper, som de arbejder ud fra:

"Though many scientists talk easily and well about the particular individual hypotheses that underlie a concrete piece of current research they are little better than laymen at characterizing the established bases of their field, its legitimate problems and methods. If they have learned such abstractions at all, they show it mainly through their ability to do successful research." (Kuhn, 1970:47). 
Det er altså ikke umiddelbart en del af indvielsen i de naturfaglige professioner, at man skal kunne formulere sig om de normer, som man arbejder ud fra inden for sit fagområde. Både Kuhn og Collins hævder derimod med henvisning til Michael Polanyis værk The Tacit Dimension (Polanyi, 1966), at den viden om normer for videnskabelighed, der findes inden for naturvidenskaberne, hovedsagelig er en tavs viden.

Mens aktørerne inden for naturvidenskabens mange forskellige fagområder derfor generelt kan siges at kende de videnskabelige normer, værdier og formål, der knytter sig til deres fag, er der altså tale om et kendskab, der antageligt overvejende har form af en tavs, praksisbundet viden, medmindre den traditionelle videreførelse af fagene suppleres med andre tilgange. At det forholder sig på denne måde betyder, at der er gode grunde til at undervise naturvidenskabelige studerende i almen videnskabsteori i FVT. Imidlertid indebærer praksisbundetheden af viden om normer for videnskabelighed, at der kan være en særlig didaktisk udfordring forbundet med at undervise i disse emner på de naturvidenskabelige uddannelser.

\section{Relevansen af FVT på de naturvidenskabelige uddannelser}

Praksisbundetheden og den tavse karakter af den forståelse, man har af sit fags normer for videnskabelighed inden for naturvidenskaben, er i sig selv vægtige grunde til, at undervisning i FVT i høj grad er relevant på de naturvidenskabelige uddannelser. Hvis man ikke er i stand til at eksplicitere disse faglige normer, og blot er blevet indkultiveret i bestemte måder at arbejde på, kan det have betydelige ulemper. Jeg vil herunder pege på en række punkter, der er centrale i den henseende.

For det første kan praksisbundetheden og implicitheden af de etablerede videnskabelige normer inden for et fagområde gøre det vanskeligt for fagets udøvere at underkaste normerne kritisk refleksion. Indlærte måder at gøre tingene på er ikke nødvendigvis hensigtsmæssige ud fra overordnede, videnskabsteoretiske hensyn, fx i forhold til idealer som objektivitet og testbarhed. Men hvis et videnskabsteoretisk tvivlsomt rationale, der ligger bag en specifik arbejdsform, ikke er ekspliciteret, kan det være vanskeligt at opdage, at det pågældende rationale er tvivlsomt. Jo bedre man er i stand til at tematisere faglige normer eksplicit ved hjælp af et kvalificeret videnskabsteoretisk begrebsapparat, jo bedre må man formodes at kunne identificere eventuelle svagheder og begrænsninger ved de måder, man arbejder på.

For det andet vil videnskabsteoretiske spørgsmål uundgåeligt trænge sig på, når nye metoder introduceres på et fagområde. I de tilfælde vil det være op til fagområdets udøvere at vurdere de pågældende metoders brugbarhed og pålidelighed, så man kan sikre sig, at deres anvendelse er i overensstemmelse med passende videnskabsteoretiske standarder. Eksempelvis kan der være behov for at overveje, hvornår en ny metodes validitet kan betragtes som tilstrækkeligt underbygget til, at metoden kan tages i brug på et givet område. 
For det tredje udgør implicitheden af faglige normer for videnskabelighed en potentiel hindring i forhold til tværvidenskabeligt samarbejde. Generelt vil der være gode grunde til, at videnskabelige undersøgelser inden for et fagområde udføres på den måde, som de gør. Samtidig vil det for fagets udøvere typisk fremstå som en selvfølge, at den specifikke måde, man gør tingene på, er den rigtige - måske endda den eneste rigtige. Men det, der betragtes som en selvfølge, når man er indkultiveret i en bestemt faglig tradition, betragtes ikke nødvendigvis som indiskutabelt af personer fra andre fagområder og fagkulturer. Når karakteren af en undersøgelsesform eller metode afspejler videnskabsteoretiske hensyn på en måde, der er særlig for et specifikt fagområde, kan undersøgelsesformen derfor både risikere at fremstå tvivlsom, fejlanbragt og unødigt kompliceret for dem, der forholder sig til den ud fra andre fagtraditioner. Misforståelser af denne type kan være et problem i forhold til tværfagligt samarbejde, fordi man i den slags sammenhænge typisk ikke vil kunne forlade sig på, at de videnskabelige retningslinjer fra et specifikt fagområde kan anvendes generelt. For at kunne håndtere eller helt undgå konflikter af denne type forekommer det nødvendigt, at man kan kommunikere på tværs af fagområder angående videnskabsteoretiske hensyn. Et veludbygget, alment videnskabsteoretisk begrebsapparat synes derfor at være en betingelse for at sikre konstruktivt samarbejde i forbindelse med tværfaglige projekter.

Endvidere vil et solidt videnskabsteoretisk udgangspunkt også kunne bidrage til at imødegå, hvad man kan betegne som fagcentriske opfattelser af videnskabelighed. Hvad forskere inden for de natuvidenskabelige fag betragter som videnskabeligt er således afhængigt af hvilket paradigme, de arbejder inden for (Kuhn, 1970:103). Men hvis man samtidig primært har kendskab til normer for videnskabelighed ved at man kender de måder at gøre tingene på, der er accepterede inden for ens eget fag, så har man umiddelbart kun ligheden med sin egen faglige praksis som målestok for videnskabeligheden af andre fags metoder og arbejdsformer. Dermed er der en betydelig risiko for, at der kan opstå en uberettiget og uhensigtsmæssig skeptisk holdning til den videnskabelige legitimitet af det arbejde, der udøves inden for fag, hvor metoder og arbejdsformer er anderledes. Et oplagt mål med undervisningen i FVT inden for de naturvidenskabelige fag vil derfor være at give de studerende de begrebslige og teoretiske redskaber, der er nødvendige for, at de også kan forstå de rationaler, der ligger bag videnskabelige tilgange, som befinder sig uden for naturvidenskabens område.

Ønsker man, at kandidater fra de naturvidenskabelige uddannelser skal være i stand til at reflektere over styrker og svagheder ved deres faglige metoder, samt kunne fungere i reelt tværfaglige samarbejdsrelationer, vil kendskabet til almene videnskabsteoretiske normer og diskussioner altså være særdeles relevant for dem. Paradoksalt nok sikrer det imidlertid ikke, at undervisning i overordnede videnskabsteoretiske spørgsmål vil fremstå relevant for de studerende. Tværtimod kan flere af de forhold, der netop gør denne form for undervisning særlig relevant, være medvir- 
kende til, at overordnede videnskabsteoretiske overvejelser vil virke irrelevante for de studerende.

Årsagen er grundlæggende, at et eksplicit kendskab til de videnskabelige normer inden for en given naturvidenskabelig profession ikke umiddelbart er en betingelse for at blive accepteret som medlem af professionen. Som Kuhn og Collins beskriver, sker denne indtræden nemlig primært gennem en indkultivering, der foregår ved, at man tilegner sig de måder at gøre tingene på, der er accepterede inden for ens fag. Ganske vist vil der være videnskabelige normer, som man forventes at følge, men fordi normerne er inkorporeret i den etablerede faglige praksis, vil en implicit, praksisbundet forståelse af dem være tilstrækkeligt til at efterleve dem i det omfang, som optagelse i professionen kræver. Eksplicit tematisering og tilegnelse af normerne kan dermed fremstå irrelevant i forhold til at opfylde betingelserne for at blive betragtet som kompetent udøver af sit fag. Og da man samtidig med rimelighed kan formode, at ønsket om optagelse i det faglige fællesskab i vid udstrækning er styrende for de studerendes motivation, risikerer man derfor, at de helt eller delvist vil mangle motivationen til at beskæftige sig med mere overordnede videnskabsteoretiske spørgsmål. Uden tilstrækkelig motivation, vil de studerende imidlertid have vanskeligt ved at mobilisere den koncentration og psykiske energi, der er nødvendig for læring - og som særligt er afgørende for læringens holdbarhed (Illeris, 2007:17). I forhold til at give de studerende en forståelse af overordnede videnskabsteoretiske diskussioner og begreber, er der derfor den betydelige didaktiske udfordring, at en afgørende forudsætning for læring vil have tendens til kun at være mangelfuldt opfyldt. Spørgsmålet er, hvordan man bedst forholder sig til denne udfordring for at kunne give de studerende det videnskabsteoretiske beredskab, der er en betingelse for at kunne samarbejde tværfagligt og forholde sig kritisk til ens egne faglige metoder.

\section{Hvordan formidler man videnskabsteoriens relevans}

Hvilken didaktisk tilgang er hensigtsmæssig, hvis man vil imødegå tendensen til, at videnskabsteoretiske overvejelser fremstår som irrelevante for de studerende på de naturvidenskabelige uddannelser på trods af, at de faktisk i høj grad er relevante for dem? Spørgsmålet kan ikke besvares detaljeret her. Jeg vil derfor blot tilegne det nogle få overordnede bemærkninger, der forekommer mig særligt vigtige.

Til det formål vil jeg begynde med at pege på to mulige tilgange, der i hvert fald ikke er hensigtsmæssige i forhold til den identificerede didaktiske udfordring. Hensigten med det er at karakterisere de to yderpunkter, som undervisningen i videnskabsteori kan placere sig imellem i forhold til den beskrevne problemstilling. Fremfor at beskrive konkret undervisning skal det efterfølgende således bidrage til at formulere et perspektiv, som undervisningen kan betragtes ud fra. Det første yderpunkt i denne optik er en tilgang til FVT, hvor videnskabsteoriens emner udelukkende præsenteres gennem behandlingen af abstrakte spørgsmål, med fokus på problemstillinger af hovedsagelig principiel, filosofisk karakter. Hvis videnskabsteori præsenteres på 
denne måde vil det være fuldstændig overladt til de studerende selv at tænke sig frem til, hvad de abstrakte diskussioner egentlig har at gøre med de konkrete arbejdsformer, der er specifikke for deres fag. Typisk vil det dermed være ekstremt vanskeligt for dem at se, hvordan videnskabsteorien er relevant for deres faglighed.

Omvendt er løsningen heller ikke at gå til det modsatte yderpunkt, hvor man forbliver så tæt på praksis, at undervisningens indhold kun adskiller sig minimalt fra en 1:1 brugsanvisning til, hvordan de studerende konkret kan udøve deres fag på en måde, der er accepteret inden for deres fagtradition. Med denne tilgang risikerer man ganske vist ikke, at undervisningen i FVT vil fremstå irrelevant i forhold til at udbygge de studerendes kompetencer inden for deres fag. Til gengæld vil den imidlertid heller ikke give de studerende den overordnede videnskabsteoretiske forståelse, der skal udruste dem til at reflektere kvalificeret over rationalet bag de metoder, der anvendes inden for deres eget fag og på andre videnskabelige områder.

En tilgang, hvor videnskabsteori kun præsenteres som abstrakte, teoretiske diskussioner, er altså ikke hensigtsmæssig i forhold til de naturlige formål med undervisning i FVT. Og det samme gælder en tilgang, hvor man blot beskæftiger sig med de etablerede, fagspecifikke retningslinjer for, hvordan et fag udøves korrekt. Hvad man i stedet bør sigte efter er en tilgang, hvor undervisningen forbinder de abstrakte, almene videnskabsteoretiske principper med de specifikke overvejelser, der er afgørende i forbindelse med konkrete videnskabelige undersøgelser inden for et fag. Det gælder med andre ord om at tilrettelægge undervisningen, så der bliver skabt sammenhæng mellem abstrakte videnskabsteoretiske spørgsmål og de fagspecifikke metoder og tilgange, som de studerende lærer at bruge på deres uddannelser. For eksempel kunne man lade de studerende arbejde med at vurdere specifikke eksempler på videnskabelige undersøgelser ud fra overordnede videnskabsteoretiske begreber og principper. Eller man kunne give de studerende til opgave at designe eller skitsere videnskabelige undersøgelser, der kan leve op til overordnede idealer for videnskabelighed. Fremfor at diskutere, hvordan disse og andre konkrete forslag nærmere kan udformes, lægger artiklen her op til, at det er en opgave, der stadig forestår. Forhåbentlig vil den på den måde bidrage til at sikre, at undervisningen $\mathrm{i}$ videnskabsteori på de naturvidenskabelige uddannelser både opleves som relevant af de studerende og samtidig udruster dem med en videnskabsteoretisk forståelse, der kan danne grundlag for tværfaglig forståelse og kritisk faglig refleksion.

\section{Konklusion}

Ud fra Kuhns og Collins' beskrivelser af naturvidenskaben kan man argumentere for, at den forståelse, som udøverne af naturvidenskabelige fag har af deres fags normer for videnskabelighed, primært består i en praksisbundet, implicit viden. Undervisning i almen videnskabsteori er derfor ekstremt relevant for de studerende på de naturvidenskabelige uddannelser i forhold til at give dem de teoretiske redskaber, der er nødvendige for, at de kan reflektere kritisk over deres egne fags metoder og 
forstå rationalerne bag andre videnskabelige tilgange. Samtidig kan praksisbundetheden af de studerendes kendskab til videnskabelige normer imidlertid bevirke, at undervisning i abstrakte, overordnede videnskabsteoretiske principper og problemstillinger fremstår irrelevant for dem i forhold til de faglige mål med deres uddannelse. For at kunne leve op til denne udfordring er det afgørende, at undervisningen i videnskabsteori i FVT tilrettelægges på en måde, der etablerer forbindelse mellem videnskabsteoriens abstrakte diskussioner og de konkrete videnskabelige problemstillinger, som de studerende møder på deres fagområder. ${ }^{2}$

Esben Nedenskov Petersen er ph.d. i Filosofi og ansat som adjunkt i Filosofi ved Institut for Kulturvidenskaber, Syddansk Universitet, hvor han er tilknyttet forskningsprogrammet Viden og værdier. Sammen med Caroline Schaffalitzky de Muckadell har han udgivet Videnskabsteori - Lærebog for sundhedsprofessionelle, Gads forlag, 2014, og artiklen "Videnskabsteoretisk refleksion som grundlaget for tværfagligt arbejde i almen studieforberedelse", Nordidactica, vol. 1, 2014. Arbejdet på denne artikel er støttet af Det Frie Forskningsråd / Kultur og kommunikation.

\section{Litteratur}

Bengson, J. \& Moffett, M. A. (2012). Knowing How: Essays on Knowledge, Mind, and Action, Oxford: Oxford University Press.

Bird, A. (2013). Thomas Kuhn, The Stanford Encyclopedia of Philosophy (Fall 2013 Edition), E. N. Zalta (red.), http://plato.stanford.edu/cgibin/encyclopedia/archinfo.cgi?entry=thomas-kuhn

Christensen, O. (2005). Fagets videnskabsteori - et større alment perspektiv, MONA, 1, s. 44-55.

Collins, H. M. (1992). Changing Order: Replication and Induction in Scientific Practice, Chicago: The University of Chicago Press.

Illeris, K. (2007). Læringsteoriens elementer - hvordan hænger det hele sammen?. In K. Illeris (red.), Læringsteorier: Seks aktuelle forståelser, Frederiksberg: Roskilde Universitetsforlag.

Kuhn, T. S. (1970). The Structure of Scientific Revolutions, 2. udg., Chicago: The University of Chicago Press.

Polanyi, M. (1966). The Tacit Dimension, London: Routledge and Kegan Paul.

Ryle, G. (1949). The Concept of Mind, Chicago: The University of Chicago Press.

Uddannelsesbekendtgørelsen (2004). Bekendtgørelse om bachelor-og kandidatuddannelser ved universiteterne, nr. 338 af 06/05/2004, https://www.retsinformation.dk/Forms/R0710.aspx?id=29192

Vestager, M. (2001). Forskning og uddannelse - interview med undervisningsminister Margrethe Vestager. In Uddanne/se, 3, http://udd.uvm.dk/200103/udd03-1.htm

\footnotetext{
${ }^{2}$ En del af denne artikels indhold er tidligere blevet præsenteret på workshoppen Philosophy of Science - First Ten Years, Københavns Universitet, 2014. Jeg er taknemmelig for de kommentarer, jeg modtog ved den lejlighed. Derudover takker jeg Birgitta Wallstedt, Rie Troelsen og Caroline Schaffalitzky de Muckadell for deres hjælpsomhed i forbindelse med artiklens tilblivelse. Endelig ønsker jeg også at takke de to anonyme bedømmere fra DUT for deres forslag til forbedringer af artiklen.
} 